\section{The politics of the ninth day of creation}

\section{Cracking the Genome: Inside the Race to Unlock Human DNA* By Kevin Davies \\ The Free Press, \$25.00, ISBN 0-7432-0479-4, 2001}

\section{Review ed by Peter N. Goodfellow}

GlaxoSmithKline Research and Development, New Frontiers Science Park, Harlow, Essex, UK

I enjoyed two Christmas presents this year. The first was on December $26^{\text {th }}$, when my local soccer team Arsenal beat Leicester City by the score of 6 to 1 . The second present I gave myself-I agreed to review the book Cracking the Genome for Nature Genetics. A relaxing read seemed to be the perfect tonic after a long year.

Kevin Davies is a trained molecular geneticist and founding editor of Nature Genetics, so he is an ideal person to relate the events that led to the sequencing of the human genome. He was there when it happened, he knows the protagonists and he was even able to influence events by contributing the occasional well-worded editorial. Cracking the Genome is written in a docu-drama style. The documentary component comes from interviews with the protagonists; the drama comes from the juxtaposition of the interviews. In the penultimate chapter, Kevin alludes to the act of creation by using the title "The eighth day." Unfortunately, this allusion has already been used. One of the first, and one of the best, examples of the science docu-drama is the book Eighth Day of Creation by Horace Judson. A perspicacious reviewer wrote of this classic story of the birth of molecular biology: "The drama has everything exploration of the unknown; low comedy and urgent seri- ousness; savage competition, vaulting intelligence, abrupt changes of fortune, sudden understandings; eccentric and brilliant people, men of honour and of less than honour; a heroine, perhaps wronged; and a treasure to be achieved that was unique and transcendent." The story of the sequencing of the human genome might represent the "ninth day of creation," but it is sadly lacking a heroine, wronged or not. According to Kevin Davies, it has all the other attributes of the Eighth Day. I am not convinced. Cracking the Genome is not about science; it is about politics, specifically American politics. The perspective from which the book is written is best summarized by its subtitle: Inside the Race to Unlock Human DNA: Craig Venter, Francis Collins, James Watson, and the Story of the Greatest Scientific Discovery of Our Time. Davies tells the story clearly and usually with technical accuracy, but his focus is on the political contributions of Venter, Collins and Watson. I have a different view of the events - both the political and the scientific.

From my political perspective, the role of the Wellcome Trust was central in catalyzing and promoting whole-genome sequencing. The cynical might argue that the large influx of funds, released by selling shares in Wellcome, left the Trust with a serious problem of what research to fund. Nonetheless, the steadfast vision behind the building of the Sanger Centre and the constant support for John Sulston was the backbone of the Human Genome Project. Cracking the Genome says almost nothing about the Wellcome Trust and even less about its politics. In contrast, many pages are devoted to politics at the National Institutes of Health.

From my scientific perspective, many key issues in sequencing the human genome are also relegated to minor roles. The public domain efforts directed at whole-genome sequencing required a map of the human genome. The heroes of mapping the human genome, for example, Victor McKusick, the father of the field, and Jean Weissenbach, whose recombination-based map transformed human genetics, are assigned only bit parts in the drama. Little is said of the disappointments of YAC-based physical maps and even less about the success of PACs, BACs and radiation-hybrid mapping. (I accept that I am showing my bias!) Again there is a striking contrast with the detailed attention paid to the development of the automated sequencers. My final complaint is that nothing is said about the relative contributions of whole-genome shotgun sequencing and directed sequencing. Did the random sequencing method work for the human genome?

Despite my caveats, I enjoyed Cracking the Genome and found it to be a good read. The anecdotes drive the story along and many people will enjoy a twinge of pleasure as they recognize the foibles of their genome heroes. I even found a link to my Saturday afternoon activities. On page 235, Arsene Wenger, the manager of Arsenal football club, is quoted discussing "explosive speed": "...and that bit is genetic. The rest is culture and education. But the genetic bit cannot be added. Not yet anyway!"

I wonder if my views on football would be of interest to readers of the matchday program? 